\title{
Pradhan Mantri Jan Dhan Yojana (PMJDY): The Biggest Financial Inclusion Initiative in the World
}

\author{
Parveen Kumar Nimbrayan ${ }^{1}$, Nitin Tanwar ${ }^{2 *}$ and Ramesh Kumar Tripathi ${ }^{3}$ \\ ${ }^{1}$ Department of Agricultural Economics, CCSHAU, Hisar-125004, Haryana, India \\ ${ }^{2}$ Department of Mathematics, Statistics \& Physics, CCSHAU, Hisar-125004, Haryana, India \\ ${ }^{3}$ Department of Agricultural Statistics, NDUA\&T, Faizabad-224229, Uttar Pradesh, India \\ *Corresponding author: nitintanwar5@gmail.com
}

\begin{abstract}
The present study seeks to review the current status of the Pradhan Mantri Jan Dhan Yojana (PMJDY) and financial inclusion in India. For the sustainable development of the Indian economy, the Government of India launches Pradhan Mantri Jan Dhan Yojana (PMJDY) on $28^{\text {th }}$ August 2014. Financial inclusion is an innovative idea which empowers the alternative techniques to encourage the banking traditions and acts as an enabler in reducing the poverty. A total of 18.28 crores accounts have been opened in rural areas by public sector bank, Regional Rural Bank (RRB) and private sector bank by $7^{\text {th }}$ Feb 2018. Thus, 31.07 crores accounts have been opened in rural and urban areas. An amount of ₹ 74534.79 crores was in accounts which were opened under PMJDY. Household coverage was 100\% in the district wise account opening report of Haryana state, while household coverage found 100 per cent in North Zone of India except J\&K (99.71\%). We can say that PMJDY scheme is playing a significant role in creating a universal platform for financial services for every citizen of India.
\end{abstract}

Keywords: Bank, financial inclusion, PMJDY, services, status

It is undoubtedly a matter of genuine worry that despite tremendous growth of banking sector in India both horizontally and vertically, a large section of Indian population continues to remain unbanked even after 68 years of independence moreover, around 600 million people in India are out of formal banking system (Singh and Pande, 2014 and Rai, 2015). Without Financial Inclusion we cannot think of economic development because a large chunk of total population remains outside the growth process (Rajanikanta, 2014).

Pradhan Mantri Jan-Dhan Yojana (PMJDY) National Mission for Financial Inclusion is based on "Sab ka Sath, Sab ka Vikas" i.e. inclusive growth to ensure access to financial services, namely, banking/ savings and deposit accounts, remittance, credit, insurance, pension in an affordable manner, launched by Prime Minister Narendra Modi on $28^{\text {th }}$ August, 2014. The launch of this scheme was announced at the historic Red Fort on the occasion of India's Independence Day. Jan Dhan Yojana roughly translates into English as "People's Wealth Scheme". The name "Jan Dhan" was chosen through an online competition on the My Govt Platform and got more than 6000 suggestions from peoples. The slogan for the mission is "Mera Khata-Bhagya Vidhaata" which when translated into English means "My Bank Account the Creator of the Good Fortune.

Keeping in the views the above facts and importance of financial services for the country as a whole, the study was conducted to review the current status of the PMJDY and financial inclusion in India.

\section{RESULTS AND DISCUSSION}

\section{History of Financial Inclusion in India}

Since 2005, many concerted measures are initiated by the Reserve Bank of India and Government of India in favour of financial inclusion, but the impact of these did not yield results (Singh et al. 2014). As 
financial inclusion initiative RBI introduced many schemes like the expansion of bank branches, post office saving bank (POSB's), sector wise lending, establishment of Regional Rural Bank (RRB's), SelfHelp Groups (SHG's) etc. Despite these initiatives, RBI did not reach the expected level of inclusions. Thus, to ensure greater financial inclusion, it took support from different SHG's and NGO's and asked for them to act as mediators through use of "Business Facilitator and Business Correspondent Model".

\section{Financial Inclusion and its Importance}

Financial inclusion is transfer of banking services at a reasonable cost to the vast sections of disadvantaged and low-income groups. A few nations across the globe now look at financial inclusion as the methods for a more comprehensive growth, wherein, every resident of the nation can utilize his/her earnings as a financial resource that they can give something to do to enhance their future monetary status and concurrently contribute to the nation's progress (www.rbi.org.in). The need for greater financial inclusion in India is well recognised. According to Census 2011, out of 24.67 crore households in the country, only 14.28 crore $(58.7 \%)$ had access to banking services. Similar data from the World Bank suggests that only $35 \%$ of people had an account in a formal institution; only $8 \%$ had borrowed from a formal financial institution in the last 12 months, only $12 \%$ saved at a financial institution in the past year and only $8 \%$ had a debit card or had used the account to receive wages (datatopics. worldbank.org). Leeladhar, V. (RBI Bulletin Jan 2006), Financial Inclusion is the conveyance of Banking administrations to the vast sections of underprivileged individuals at a moderate cost. As Banking administrations are dealt with as public utility services, it is essential that accessibility of banking and payment services be made available to all natives of the nation with no separation. Thorat, U. (2008), Deputy. Governor, Reserve Bank of India has stressed the requirement for Financial Inclusion as the key to sustainable growth amid her address on 'Vision-2020- Indian Financial Services Sector' facilitated by national television channel NDTV. She highlighted the rising difficulties in the coming days that require building synergy between Micro Finance Institutions and Self-Help Groups and
Banks for implementing ICT based seamlessly also advocated that Financial Inclusion requires skilled manpower to manage IT platform successfully.

\section{Status of Financial Inclusion in India}

Table 1 shows a dismal situation in Inclusix index of 2009 and 2010 while in 2011 nearly progress in the development of financial inclusion in India and highest progress in Southern Region of the country.

Table 1: Financial Inclusion at a regional level

\begin{tabular}{cccc}
\hline Region & $\begin{array}{c}\text { Inclusix } \\
\mathbf{2 0 1 1}\end{array}$ & $\begin{array}{c}\text { Inclusix } \\
\mathbf{2 0 1 0}\end{array}$ & $\begin{array}{c}\text { Inclusix } \\
\mathbf{2 0 0 9}\end{array}$ \\
\hline India & 40.1 & 37.6 & 35.4 \\
Southern Region & 62.2 & 58.8 & 54.9 \\
Western Region & 38.2 & 35.8 & 33.9 \\
Northern Region & 37.1 & 34.8 & 33.3 \\
Eastern Region & 28.6 & 26.3 & 24.3 \\
North-Eastern Region & 28.5 & 26.5 & 23.8 \\
\hline
\end{tabular}

Source: CRISIL (2013).

Table 2 reported that there was huge difference between March 2010 to March 2014 banking outlets in villages-branches, basic savings bank deposit $\mathrm{A} / \mathrm{c}$ through branches (No. in millions), overdraft facility availed in basic savings bank deposit accounts (No. in millions).

Table 2: Financial Inclusion Progress: Banks and RRBS

\begin{tabular}{lcc}
\hline Particulars & $\begin{array}{c}\text { Year ended } \\
\text { March 2010 }\end{array}$ & $\begin{array}{c}\text { Year ended } \\
\text { March 2014 }\end{array}$ \\
\hline $\begin{array}{l}\text { Banking Outlets in Villages- } \\
\text { Branches }\end{array}$ & 33,378 & 46,126 \\
$\begin{array}{l}\text { Banking Outlets in Villages- } \\
\text { Branchless Mode }\end{array}$ & 34,316 & $3,37,678$ \\
$\begin{array}{l}\text { Banking Outlets in Villages- } \\
\text { Total }\end{array}$ & 67,694 & $3,83,804$ \\
$\begin{array}{l}\text { Urban Locations covered } \\
\text { through BCs }\end{array}$ & 447 & 60,730 \\
$\begin{array}{l}\text { Basic Savings Bank Deposit } \\
\text { A/c through branches (No. in } \\
\text { millions) }\end{array}$ & 60.2 & 126.0 \\
$\begin{array}{l}\text { Basic Savings Bank Deposit } \\
\text { A/c through branches (Amt. in } \\
\text { billions) }\end{array}$ & 44.3 & 273.3 \\
$\begin{array}{l}\text { Basic Savings Bank Deposit A/c } \\
\text { through BCs (No. in millions) }\end{array}$ & 13.3 & 116.9 \\
$\begin{array}{l}\text { Basic Savings Bank Deposit A/c } \\
\text { through BCs (Amt. in billions) }\end{array}$ & 10.7 & 39.0 \\
\end{tabular}


Basic Savings Bank Deposit

73.5

243.0

Accounts Total (No. in millions)

Basic Savings Bank Deposit

55.0

312.3

Accounts Total (Amt. in billions)

Overdraft facility availed in

Basic Savings Bank Deposit

Accounts (No. in millions)

Overdraft facility availed in

Basic Savings Bank Deposit

Accounts (Amt. in billions)

KCCs - (No. in millions)

KCCs - (Amt. in billions)

GCC - (No. in millions)

$1,240.1$

$3,684.5$

1.4

7.4

GCC - (Amt. in billions)

Communication Technology A/

Cs-BC- Transaction - (No. in

millions) (During the year)

Information and

Communication Technology A/

Cs-BC- Transactions - (Amt. in

billions) (During the year)

Source: RBI Annual Report (2013-14).

\section{Policies Supporting Financial Inclusion}

Policymakers and regulators have found a way to help financial inclusion at both the national and global level. Some have likewise looked to upgrade financial literacy, while others have focused on accomplishing numerical inclusion targets. Regulators in numerous jurisdictions have played a central role. For example, the Reserve Bank of India has relaxed the prerequisites for opening bank accounts, recommended the availability of accounts with a minimum number of functions and encouraged banks to expand their branch networks (Bhaskar, 2013). In many Latin American countries, including Brazil, Colombia, and Peru, agent banking regulations have been passed to energize "branchless banking", i.e. the delivery of financial services outside conventional bank branches (AFI, 2012). International standard setters, including the Basel Committee on Banking Supervision and the Committee on Payments and Market Infrastructures, have addressed regulatory and supervisory issues. As an example, financial inclusion has been a driving force behind financial innovation (CPSS, 2012). Finally, some national policymakers have committed to achieving financial inclusion targets. Internationally, over 60 central banks, plus other public-sector institutions, from more than 90 countries were part of the Alliance for Financial Inclusion (AFI), a member-driven peer learning network. Some have agreed to quantifiable goals by signing the Maya Declaration. For instance, the Central Bank of Nigeria has committed to reducing the share of the adult population that was excluded from financial services from $46 \%$ to $20 \%$ by 2020 , with additional specific targets for various sorts of key services (AFI, 2014).

\section{Pradhan Mantri Jan Dhan Yojana (PMJDY)}

Financial inclusion is a creative idea which empowers the elective procedures to promote the banking habits and acts as an enabler in reducing the poverty. The launch of Pradhan Mantri Jan Dhan Yojana (PMJDY) by Government of India is toward that path. The scheme is not just limited to opening a bank account but additionally has different advantages with it viz. zero balance bank account with RuPay debit card, notwithstanding accidental insurance cover of ₹ 1 lakh, those who open accounts by January $26^{\text {th }}, 2015$ over and above the ₹ 1 lakh accidental cover, they will be given life insurance cover of ₹ 30,000, etc. According to GOI, Mahatma Gandhi National Rural Employment Guarantee Act (MGNREGA) payments are to be done into the accounts of the MGNREGA laborers in rural areas held either in Banks/ Post Offices (unless exempted). The target of the PMJDY scheme is to guarantee that no household is left without a bank account. There are total 9.98 Crore accounts of the MGNREGA worker in Bank/ Post Offices. Out of this, there are 3.66 Crore accounts in Post Offices and 0.75 Crore in Co-operatives. In this manner, all banks were coordinated to work toward this path for more inclusion (nrega.nic.in).

\section{Objectives of PMJDY}

PMJDY has six important objectives out of which first three will be fulfilled in the first year of launching of this scheme. It comprises the following six pillars:

A. Universal access to banking facilities: To ensure in-depth extension of banking facilities each district is divided into Sub Service Area (SSA) to confirm access to banking facilities within $5 \mathrm{~km}$ range by 14 August 2015. Some of the countries which 
has accessibility and connectivity problem will be covered in phase-II of the program.

B. Banking accounts with RuPay debit card with the provision of overdraft facility: The primary aim is to open a basic account of each household in the country. A RuPay debit card is also provided with each account. In future, there will be the provision of over drafting up to ₹ 5000 after successful operating debit card for 6 months. There will be the nominal interest rate on overdraft money and, it will also act as micro finance scheme.

C. Financial literacy programme: Majority of villagers are illiterate. Thus, there is a need to run financial literacy programme. The main aim of such program is to make people aware and capable of using financial services provided by banks.

D. Creation of credit guarantee fund: In future government has planned to create a credit guarantee fund that will be used to cover the defaults in overdrafts accounts.

E. Micro finance: Government will provide micro finance to all willing and eligible persons. This objective will be fulfilled in $2^{\text {nd }}$ phase of PMJDY.

\section{Phases of Pradhan Mantri Jan Dhan Yojana}

The complete action plan to achieve 100 per cent financial inclusion in the country is divided into two phases as follows:

\section{Phase-I (15 Aug, 2014 - 14 Aug 2015)}

There were four primary objectives in Phase-I. These objectives are outlined as:

1. To ensure universal access to banking facilities throughout the country except for areas with infrastructure and connectivity constraints.

2. To provide basic banking accounts and RuPay debit card.

3. To facilitate each account holder accident insurance covers of ₹ $1,00,000$.

4. To implement Financial Literacy Programme
Phase-II (15 Aug. 2015 - 14 Aug 2018)

The objectives for Phase-II are listed below:

1. To ensure overdraft facility up to ₹5 000/after six months of satisfactory operation of the account.

2. To create credit guarantee fund for coverage of defaults in overdraft account.

3. To promote micro finance scheme.

4. To cover geographical areas left in phase-I due to infrastructure and connectivity problem.

5. To promote financial inclusion program up to individual level covering adults and students of each household.

\section{Status of PMJDY}

Table 3 reported the status of accounts opened under PMJDY. In rural areas $(7,17,89,697)$ accounts opened by public sector banks, RRB's and private sector banks were 5,33,00,249, 1,84,89,448 and 32,26,397, respectively. However, in urban areas $(4,84,45,109)$ accounts opened by public sector banks, RRB's and private sector banks were 4,51,47,276, 32,97,833 and $20,12,086$, respectively. Thus, the total accounts opened in the rural and urban area by public sector bank, RRB and private sector bank were 9,84,47,525, $2,17,87,281$ and $52,38,483$, respectively. The grand total of opened accounts was $12,02,34,806$. Awasthi (2015) reported that financial inclusion is one of the most powerful ways to alleviate poverty as India is the home for about one-third of the poor people in the world, who don't have access to financial services.

Table 3: Status of PMJDY (Accounts Opened as on 31.01.2015)

\begin{tabular}{ccccc}
\hline & $\begin{array}{c}\text { Public } \\
\text { Sector Bank }\end{array}$ & RRB & $\begin{array}{c}\text { Private } \\
\text { Sector Bank }\end{array}$ & Total \\
\hline Rural & $5,33,00,249$ & $1,84,89,448$ & $32,26,397$ & $7,17,89,697$ \\
Urban & $4,51,47,276$ & $32,97,833$ & $20,12,086$ & $4,84,45,109$ \\
Total & $9,84,47,525$ & $2,17,87,281$ & $52,38,483$ & $12,02,34,806$ \\
\hline
\end{tabular}

Source: $h$ htp://pmjdy.gov.in/account

Data revealed from Table 4 show that total accounts were opened 31.07 crores. Highest accounts (13.47 crores) were opened in rural areas by public sector bank followed by RRB (4.21 crores) and private 
sector bank ( 0.60 crores). However, in case of urban, public sector bank (11.62 crores) followed by RRB's ( 0.78 crores) and private sector banks (0.39 crores). Thus, total accounts opened in rural and urban areas were 18.28 and 12.79 crores.

Table 4: Status of PMJDY (Accounts Opened as on 07.02.2018) (in Crores)

\begin{tabular}{ccccc}
\hline & $\begin{array}{c}\text { Public } \\
\text { Sector Bank }\end{array}$ & RRB & $\begin{array}{c}\text { Private } \\
\text { Sector Bank }\end{array}$ & $\begin{array}{c}\text { Grand } \\
\text { Total }\end{array}$ \\
\hline Rural & 13.47 & 4.21 & 0.60 & 18.28 \\
Urban & 11.62 & 0.78 & 0.39 & 12.79 \\
\hline Total & $\mathbf{2 5 . 0 9}$ & $\mathbf{4 . 9 9}$ & $\mathbf{0 . 9 9}$ & $\mathbf{3 1 . 0 7}$ \\
\hline
\end{tabular}

Source: $h$ ttp://pmjdy.gov.in/account

\section{Disclaimer: Information is based on the data as submitted by different banks/SLBCs}

Awasthi (2015) concluded that the schemes of the Government do not reach to the poor people because of their lack of financial literacy, corruption and others. Financial inclusion can help in poverty eradication, economic empowerment and inclusive growth. So, we can say that PMJDY helps the poor people to open accounts and motivate the people for saving. Financial inclusion or inclusive financing is the delivery of financial services at affordable costs to vast sections of disadvantaged and lowincome segments of society, in contrast to, financial exclusion where those services are not available or affordable. An estimate of 2.5 billion working-age adults globally has no access to the types of formal financial services delivered by regulated financial institutions (Kumar, 2014).

Table 5: Balance in accounts under PMJDY (as on 07.02.2018) (in crore)

\begin{tabular}{cc}
\hline & Balance in Accounts \\
Public Sector Bank & 59719.59 \\
RRB & 12622.27 \\
Private Sector Bank & 2192.93 \\
\hline Total & $\mathbf{7 4 5 3 4 . 7 9}$ \\
\hline
\end{tabular}

Source: $h$ ttp://pmjdy.gov.in/account

An examination of results regarding balance in accounts present in Table 5 indicates that public sector banks have maximum balance in accounts (₹ 59719.59 crore) followed by RRB's (₹ 12622.27 crore) and private sector bank ( $₹ 2192.93$ crore).
Tapeja (2015) also reported that 70 per cent of the total accounts opened under PMJDY were opened with zero balance depicting the weakness in the implementation strategy of the plan regarding easy access to the banking system.

\section{Disclaimer: Information is based on the data as submitted by different banks/SLBCs}

Table 6 concluded that all allotted wards-SSAs have a survey done in all districts of Haryana state which have 100 per cent household coverage. Maximum allotted wards-SSAs to Hisar (401) followed by Fatehabad, Karnal, Sirsa and Sonipat, i.e. 364, 349, 311 and 278, respectively, whereas, Faridabad (96) have minimum allotted wards-SSAs.

Table 6: District wise account opening report of Haryana state (as on 07.02.2018)

\begin{tabular}{cccc}
\hline & $\begin{array}{c}\text { Allotted } \\
\text { Wards-SSAs }\end{array}$ & $\begin{array}{c}\text { Wards-SSAs } \\
\text { Survey Done }\end{array}$ & $\begin{array}{c}\text { Household } \\
\text { Coverage } \%\end{array}$ \\
\hline Ambala & 234 & 234 & $100.00 \%$ \\
Bhiwani & 248 & 248 & $100.00 \%$ \\
Faridabad & 96 & 96 & $100.00 \%$ \\
Fatehabad & 364 & 364 & $100.00 \%$ \\
Gurgaon & 183 & 183 & $100.00 \%$ \\
Hisar & 401 & 401 & $100.00 \%$ \\
Jhajjar & 205 & 205 & $100.00 \%$ \\
Jind & 258 & 258 & $100.00 \%$ \\
Kaithal & 274 & 274 & $100.00 \%$ \\
Karnal & 349 & 349 & $100.00 \%$ \\
Kurukshetra & 275 & 275 & $100.00 \%$ \\
Mahendragarh & 203 & 203 & $100.00 \%$ \\
Mewat & 246 & 246 & $100.00 \%$ \\
Palwal & 162 & 162 & $100.00 \%$ \\
Panchkula & 74 & 74 & $100.00 \%$ \\
Panipat & 153 & 153 & $100.00 \%$ \\
Rewari & 207 & 207 & $100.00 \%$ \\
Rohtak & 161 & 161 & $100.00 \%$ \\
Sirsa & 311 & 311 & $100.00 \%$ \\
Sonipat & 278 & 278 & $100.00 \%$ \\
Yamunanagar & 188 & 188 & $100.00 \%$ \\
\hline
\end{tabular}

Source: $h t t p: / / p m j d y . g o v . i n / a c c o u n t$

Table 7 clearly shows that household has 100 per cent coverage in Haryana, Punjab, H.P., Uttarakhand, Delhi and Chandigarh except for J\&K and U.P. In J\&K total household were 357340 and 356295 were covered while in U.P. total household were 31159992 and 31159148 were covered. In other 
Table 7: North Zone account opening report (as on 07.02.2018)

\begin{tabular}{cccccc}
\hline & $\begin{array}{c}\text { Allotted Wards- } \\
\text { SSAs }\end{array}$ & $\begin{array}{c}\text { Wards-SSAs } \\
\text { Survey Done }\end{array}$ & Total Household & $\begin{array}{c}\text { Covered } \\
\text { Households }\end{array}$ & $\begin{array}{c}\text { Household } \\
\text { Coverage \% }\end{array}$ \\
\hline Haryana & 4870 & 4870 & 4596617 & 4596617 & $100.00 \%$ \\
Chandigarh & 136 & 136 & 193876 & 193876 & $100.00 \%$ \\
Punjab & 6743 & 6743 & 4746147 & 4746147 & $100.00 \%$ \\
Delhi & 266 & 266 & 2696322 & 2696322 & $100.00 \%$ \\
Himachal Pradesh & 2489 & 2489 & 1298191 & 1298191 & $100.00 \%$ \\
JAMMU \& KASHMIR & 604 & 604 & 357340 & 356295 & $99.71 \%$ \\
Uttarakhand & 2769 & 2769 & 1136431 & 1136431 & $100.00 \%$ \\
Uttar Pradesh & 37424 & 37424 & 31159992 & 31159148 & $100.00 \%$ \\
\hline
\end{tabular}

Source: http://pmjdy.gov.in/account

words, household covered in J\&K and U.P were 99.71 and 100 per cent, respectively.

\section{Challenges in Implementing PMJDY}

The exceptional theory of the programme PMJDY is a major move to convey the rejected helpless peoples to the overlay of the formal financial system, yet a portion of the difficulties may influence its viability if not observed and managed adequately as detailed below:

\section{The issue of Multiple of accounts}

The scheme is essential for the unbanked, but it is not adequately clear the individuals who are poor and having a bank account are eligible to open an account and avail the benefits of the scheme. The commanding of a single identity proof to open an account supports any expectation of higher insurance cover and overdraft in multiple accounts for which no robust mechanism has not been put in place.

\section{Infrastructural issues}

The big volume of 22.81 crore Rupay debit cards to be issued under Jan Dhan Yojana and existing volume of 120 million Rupay Kisan Cards when combined are likely to pose a problem. The infrastructural bottlenecks like poor broadband connectivity and poor power supply to ATMs, downtime of ATMs and so on may also pose a big challenge. There is the likelihood of long queues at ATMs and a higher risk of misuse and cheats due to lack of knowledge about ATM use is a possibility.

\section{Financial literacy}

Awareness efforts are the major stigma that deters the optimum use of alternate channels and stimulate demands for using financial services. Without financial literacy, the initiative would be half backed.

\section{Inactive accounts}

The government is intense that each unbanked family has at least two bank accounts (including one for a female member of the family). To deal with a heap of no decoration essential bank accounts both existing and new the programme must guarantee that regular flow of funds through Direct Benefits Transfer from the government to individuals holds the way to progress.

\section{Idleness of overdraft}

The nonappearance of any solid system of utilization of the proposed overdraft of ₹ 5000/- per household in 7.5 crore accounts may prompt potential awful obligations of the huge amount which is posing a potential threat upcoming. Many unbanked people don't know whether the amount is to be reimbursed back to Bank or simply the same is a grant for which literacy initiative may help mitigate the dread.

\section{Confusion regarding the validity of insurance claims}

The life insurance is an inbuilt feature of the Rupay Debit Card, and the insurance claim is acceptable only if the Rupay Card is considered active when the card is swiped inside the stipulated time limit of 45 days before making a claim. In this way, to 
keep the account and card active under PMJDY, it is essential that the status of the card should be maintained as active by utilizing it in once every month.

\section{Less availability of ATMs in rural areas}

The huge number of debit cards proposed to be issued will be used to the benefit of excluded people if the requisite number of ATMs is available in rural areas.

\section{Other issues}

The major players like cooperative societies, banking or respondents, mobile service providers, postal service and new payment banks may be roped in and role synchronised for yielding the desired result. HR required proposing the branch expansion needs to overcome, and proper coordination between RBI and government is the need of the hours for effective implementation. There should be a close link between Bank officials and Banking Correspondent (BC) outlets The Rupay cards are to be swiped at least once in every 45 days to maintain the active status of the card which should be scattered to the common public on a wide scale.

\section{Problems in Information and communication technology (ICT) transactions}

The manifold increase in ICT transactions in the proposed scheme is linked to other infrastructural needs such as the broadband connections and electricity supply in remote area villages. The handheld devices may also face problems to identify the biometrics of labourers and the old for Aadharenables Direct Benefit Transfers.

\section{Role of Technology in Financial Inclusion (www.financialservices.gov.in)}

1. Technology and financial inclusion are the prevalent coinage in banking parlance in the nation. The principle leap in financial inclusion so far has been large numbers and low volumes, converting into exorbitant expenses. The best way to cut down the cost an affordable level and to improve the reach to enhance the range to the most remote/ remotest corner of the nation is by viably utilizing the technology.
2. To make available the banking facilities over the length and broadness of the nation, most recent technological products like e-KYC, IMPS, mobile banking and so on can possibly develop as a distinct advantage with respect to costs, accommodation and speed of reach.

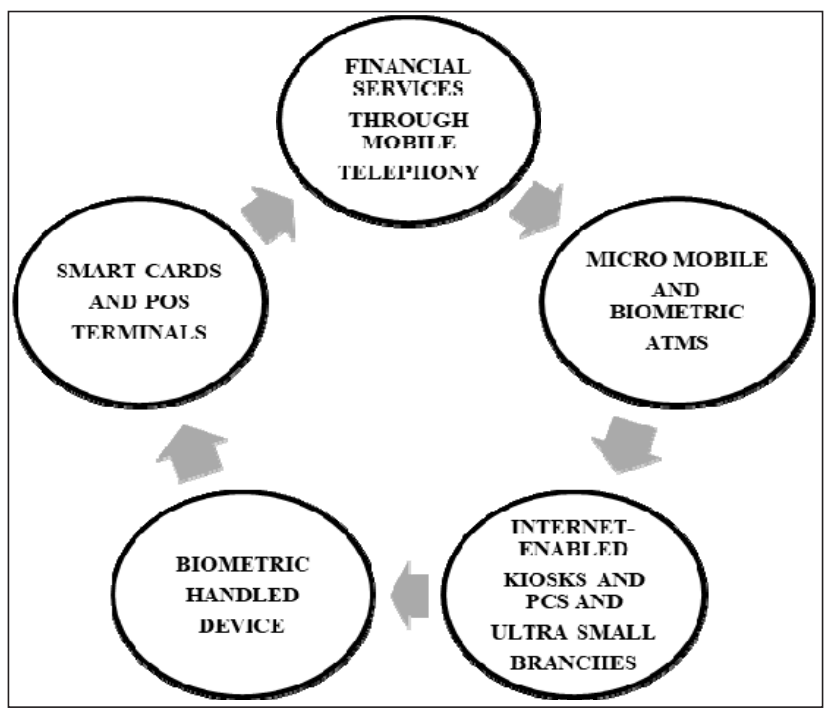

Fig. 1: Role of Technology in Financial Inclusion

4. Reserve Bank has, thus, been actively involved in harnessing technology for the development of the Indian banking sector over the years. Major technological development in the banking sector is the adoption of the Core Banking Solutions (CBS). Which is a step towards enhancing, customer convenience through, any-where, anytime banking. It is important to leverage this technological advancement to look at areas beyond CBS that can help not only in delivering quality and efficient services to customers but also generating and managing information effectively. The adoption of CBS led to various technological products like NEFT, RTGS, mobile banking, Internet Banking, ATMs, etc. Some of the Technological based products have made significant changes in the banking outreach to the masses are appended below:

Adopting core banking solution (CBS) by the Banks, including all Regional Rural Banks (RRBs). Next, a multi-channel branchless approach using handheld devices, mobiles, cards, micro-ATMs and kiosks can be used. 
$\square$ Transactions put through such front-end devices are seamlessly integrated with the banks' CBS.

$\square$ Implementation of the electronic payment system such as RTGS (Real Time Gross Settlement),

Electronic Clearing Service (ECS),

$\square$ National Electronic Funds Transfer (NEFT),

$\square$ Cheque Truncation System (CTS),

$\square$ Banking transaction by using Mobile phones etc.

5. The present plan of the PMJDY under National Mission on Financial Inclusion proposed to use the Technology in a big way to achieve the goal in a time-bound manner such as Electronically Know Your Customer (e-KYC), Transaction through mobile banking, Immediate Payment System (IMPS), RuPay Debit cards etc.

\section{CONCLUSION}

Financial Inclusion will help the poor in bringing them to the mainstream of growth and would also provide the financial institutions an opportunity to be partners in inclusive growth. Financial inclusion is the essence of sustainable economic growth and development in a nation like India. Inclusive growth winds up inconceivable without financial inclusion. Financial inclusion is likewise shall for the economic development of the nation. Overall, the PMJDY is an ambitious financial inclusion plan.

\section{REFERENCES}

Alliance for Financial Inclusion. "Agent banking in Latin America”, AFI Discussion Paper, March 2012

Alliance for Financial Inclusion. The 2014 Maya Declaration progress report: measurable goals with optimal impact. 2014.
Amita, S. and Tapeja, S. 2015. Pradhan Mantri Jan Dhan Yojana: A vehicle for financial inclusion. Indian Journal of Economics and Development, 2: 499-508.

Awasthi A. Comparative analysis of pradhan Mantri Jan Dhan Yojana. Advances in Economics and Business Management (AEBM). 2015: 2(4): 336-340.

Bhaskar P. "Financial inclusion in India-an assessment", speech at the MFIN and Access-Assist Summit, New Delhi, 10 December, 2013.

Committee on Payment and Settlement Systems. Innovations in retail payments, report by the Working Group on Innovations in Retail Payments. 2012.

CRISIL. 2013. "Inclusix Financial Inclusion Index”. June.

Kumar D. 2014. Financial inclusion using Pradhan Mantri Jan-Dhan Yojana-A conceptual study. Asia Pacific Journal of Research, 1(20): 37-44.

Leladhar V. 2006. Taking Banking Services to Common ManFinancial inclusion: RBI, Bulletin, Jan.

Rai, S. 2015. Pradhan Mantri Jan Dhan Yojna: An ambitious plan for financial inclusion. Research Front, 3(2): 25-32.

Rajanikanta K. 2014. Pradhan Mantri Jan Dhan Yojana (PMJDY): A new drive towards financial inclusion in India. Zenith International Journal of Business Economics and Management Research, 4(11): 10-20.

Reserve Bank of India. Annual Report 2013-14.

Singh, C., Mittal, A., Goenka, A., Goud, C.R.P., Ram, K., Suresh, R.V., Chandrakar, R., Garg, R. and Kumar, U. 2006. Financial Inclusion in India: Select Issues. Working Paper No: 474.

Singh, S.S. and Pande, J.P. 2014. Pradhan Mantri Jan Dhan Yojana: A Giant Leap Towards Financial Inclusion. International Journal of Research in Management and Business Studies, 1(4): 19-22.

Usha, T. 2008. Deputy Governor, Reserve Bank of India, Speech delivered on Vision -2020-Indian Financial Services Sector hosted by NDTV in September 2008. 